\title{
OUTBREAKS OF THE \\ TENTCATERPILLAR (MALACOSOMA NEUSTRIA L.) ON ELM TREES IN AMSTERDAM AND THE EFFORTS TO CONTROL THEM WITH DERRIS-POWDER
}

\author{
by
}

\author{
L. G. E. KALSHOVEN \\ Blaricum, Netherlands
}

\section{INTRODUCTION}

After an interlude of five years-from 1949 until 1953 -during which period no trouble worth mentioning had been caused by the tentcaterpillars to the renowned rows of elm trees along the canals and avenues of Amsterdam, considerable defoliation occurred in the north-west part of the canal-zone in the early summer of 1954. This outbreak had not been foreseen and had manifested itself in spite of the annual routine dusting with derris/talcum powder which had been carried out in June.

As it was feared that this might be the beginning of a new cycle of defoliations as experienced in previous periods, the present writer-in his function of entomologist at the Royal Institute for the Tropics, one of the advisory boards in this matter-decided to make a study of the history of the Malacosoma outbreaks and the measures for their control, using the data available since 1930 and particularly gathered since 1936. It was in the latter year that the local authorities set up a "Commissie ter bestudering van middelen tot bestrijding van de rupsenplaag in Amsterdam" (Committee for investigation of measures to control caterpillar outbreaks in Amsterdam), after which campaigns for reducing and preventing defoliations were started in 1937.

An extensive report was presented to the said Committee in February 1955 to serve as a base for a renewed discussion about the somewhat doubtful efficacy of the control measures so far used, and for suggestions concerning improvements in the organization and execution of these measures.

The Committee strongly advised an early publication of the report, after due condensation of its contents, in order that it might be used for the instruction of the personnel of the municipal services and for information of other people interested.

However, after the condensed report had been finished the expected opportunity to have it officially printed failed to materialize.

An excerpt of the paper, illustrated with slides, was read at the meeting of the Section for Applied Entomology of the Nederlandse Entomologische Vereniging in Amsterdam on 31.1.1956.

In preparing the condensed report and its present translation, I have had the very valuable assistance of Dr. F. E. Loosjes and Dr. P. A. van der LaAn, who both have worked on the problem during the early stages of the campaign and could give me various explanations. I am also indebted to the Plantenziektenkundige Dienst in Wageningen for the loan of clichés, and to the Koninklijk Instituut voor de Tropen in Amsterdam for the free use of notes and photographs from its archives.

\section{THE 1930/1931 OUTBREAK}

Exceptionally severe defoliation of the large elm trees by tentcaterpillars occurred in Amsterdam in the year 1930. Many lines of trees along the most important canal-sections were wholly deprived of their foliage in the second half of June. Clippings from the daily papers, preserved in the files of the late J. R. KonING, then Chief of the Municipal Parks and Plantation Service, clearly show the alarm caused by the dense crowds of caterpillars foraging on the leaves and spreading over the streets and houses.

The outbreak had started already in 1929 when defoliated branches and crowns of the trees that had 
only a thin foliage left had been observed in various places while many larval nests had been visible. This had been reported notably for the section of the Heerengracht between the Nieuwe Spiegelstraat and the Leidsche Straat.

However the outbreak in 1930 was far more serious and the question "Can nothing be done in this matter?" was repeatedly posed in the Town Council and in letters to the press. However, the authorities and experts felt rather helpless in face of such an enormous and extensive outbreak of caterpillars. Some results were expected from the clipping and destroying of the egg-rings in the crowns of the trees, but this could not be done before the next winter and a large number of trained climbers would have to be employed. Even then it could be foreseen that a sufficiently complete removal of the egg-rings (Fig. 1), sticking to the outermost parts of the crowns, might be practically unattainable so that enough of them would be left for a renewed outbreak in the next year. The application of contact and stomach insecticides-almost exclusively highly poisonous, arsenic-containing chemicals at that time-was thought to be too dangerous for the towns-people.

Professor L. PH. DE Bussy, the late director of the "Handelsmuseum of the Colonial Institute"-today the Division of Tropical Products of the Royal Institute for the Tropics-having much experience on the control of caterpillar pests in the tobacco fields of Deli, Sumatra, and acting as one of the advisers in the matter, was strongly opposed to the use of the poisonous materials in a large town, not the least with regard to the psychological effect. The people would certainly be inclined to impute all kinds of diseases and indispositions to the use of large quantities of poisonous material in the densely populated quarters.

Therefore, the measures against the pest were restricted to hitting the tree-crowns with strong jets of water from hoses, and the sweeping of the caterpillars which had fallen down or descended from the trunks, all by the personnel of the Municipal Cleaning Service. For the rest the outbreak, which in its most severe stage lasted a few weeks, had to be left to subside through natural causes.

The next year a credit of $\mathrm{fl} .10 .000$ was voted by the Town Council in April for clipping egg-rings and larval nests (Fig. 2) and for similar measures. However, when the activity of the caterpillars became conspicuous again in the middle of June, recourse was again had to the removal of the insects by jets of water, in which treatment the fire brigade also joined. To prevent the caterpillars from re-ascending the trees a strip of tar was laid around the base of the trunks. On a press-conference held those days, T. A. L. Schoevers, Senior Officer of the Plantenziektenkundige Dienst (the Phytopathological Service) at Wageningen, gave an explanation of the difficulties to be overcome in the control of outbreaks under the prevailing circumstances.

From the news columns published at the time it appears that the caterpillars had not reappeared in 1931 in the lines of trees which had been defoliated in the Centrum of the town in the previous year, but that they had been most numerous in other parts, notably in the eastern district (Amsterdam Oost).

It cannot be estimated from the notes left to what extent the outbreak developed in 1931 but apparently most trees had recovered their normal foliage again in the middle of July.

\section{INSTITUTION OF THE COMMITTEE IN 1936}

Caterpillars became front news again in 1936 when apprehension was expressed particularly concerning a further extension of an outbreak of the brown-tail moth, Euproctis chrysorrhoea Don., which had begun to appear in the oak trees of the Vondelpark in 1935 and now threatened these trees with defoliation again as well as other trees along the canals, and in private gardens. Moreover these kind of caterpillars had caused much trouble because many persons and young children appeared to be sensitive to the fine hairs shed and scattered by these insects.

As the remembrance of the caterpillar outbreak of $1930 / 1931$ was still vivid, J. R. Koning urged the necessity for the establishment of a committee of ex- perts to advise in the matter of combating the pests and the Town Council agreed to this proposal on 1 May 1936. Preliminary deliberations had already taken place before this date in which attention had been focussed on a comparatively new insecticide, viz. the rotenon containing derris powder, non poisonous for man and domestic animals and therefore promising for its use under urban conditions. The investigations carried out at the Tropical Institute concerning the properties of the insecticide, obtained from the roots of plants growing in the tropics, had much contributed to its first introduction and it had already been shown that the caterpillars of Malacosoma and Euproctis could be killed with it (see 


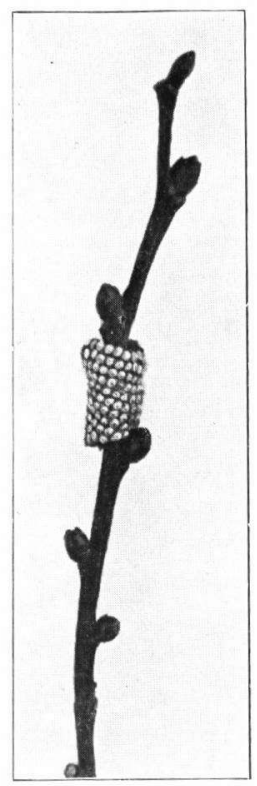

Fig. 1. Egg-ring of Malacosoma neustria

(Cliché van de Plantenziektenkundige Dienst).

Fig. 2. Caterpillars of Malacosoma neustria on their webb. (Cliché van de Plantenziektenkundige Dienst te Wageningen).

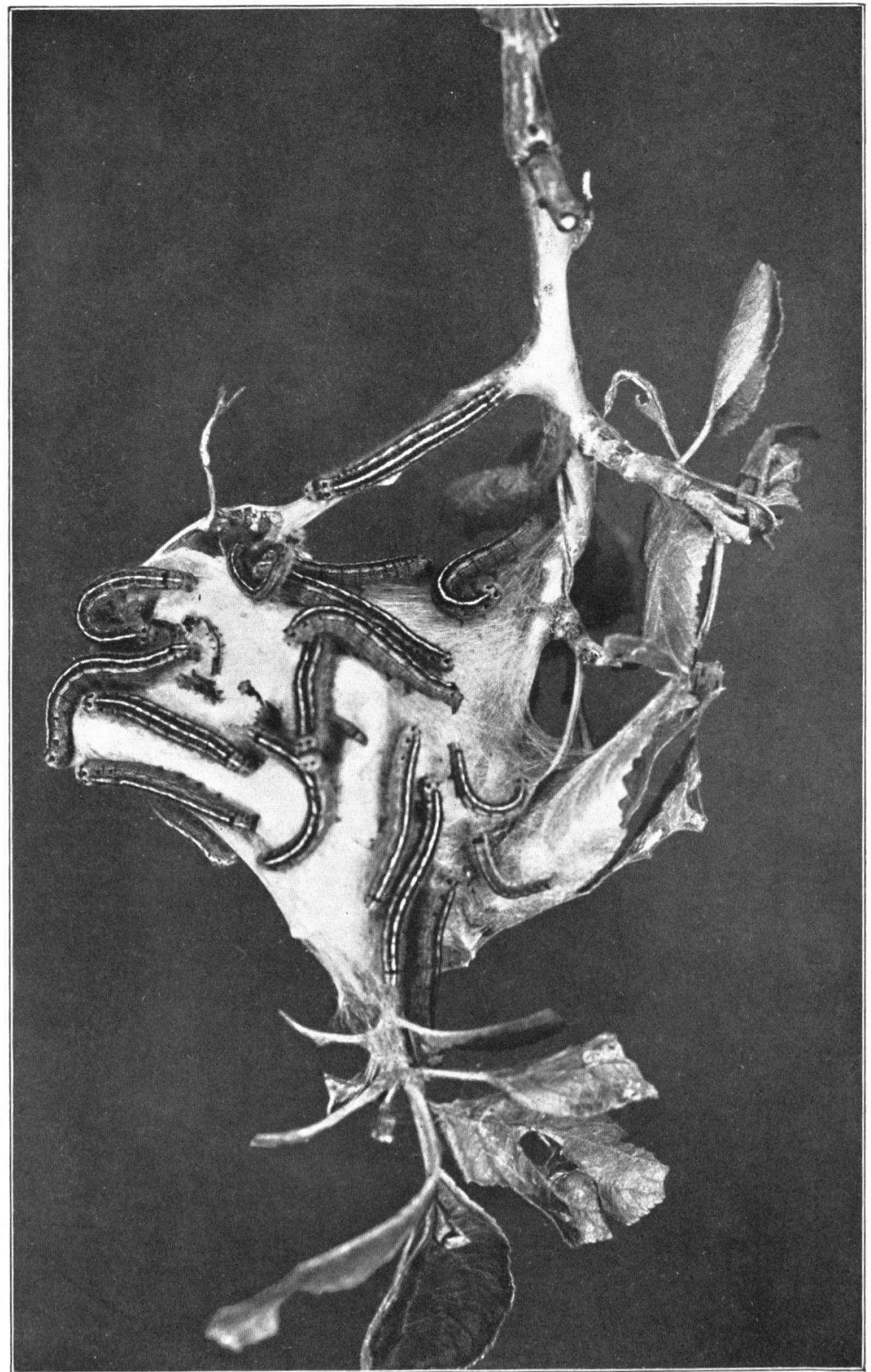




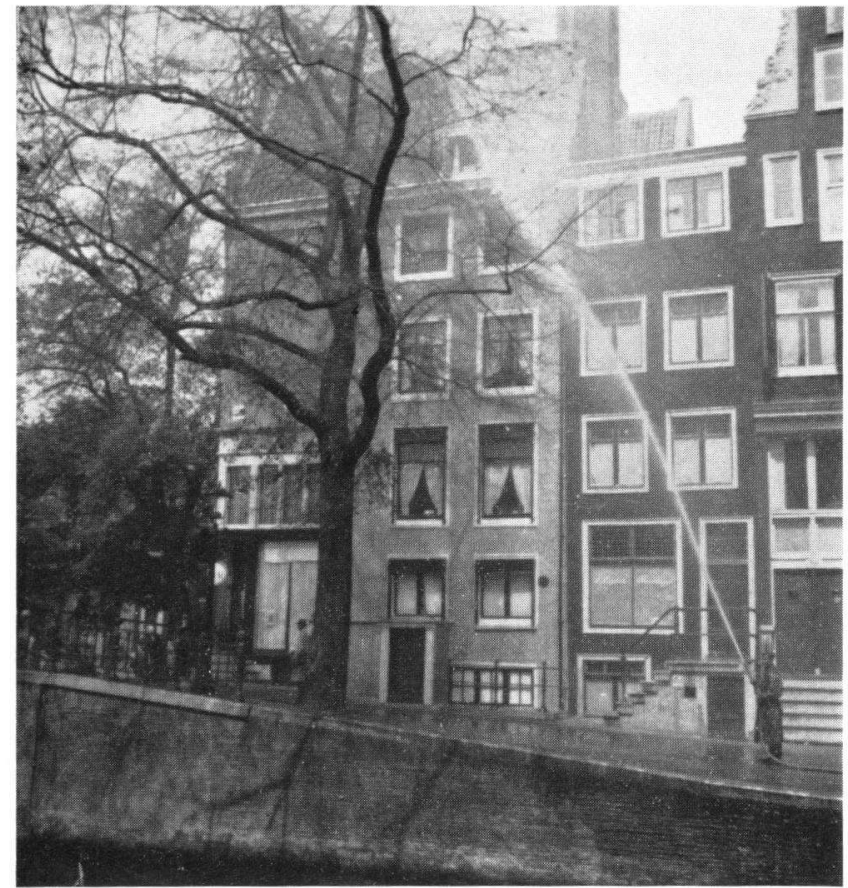

Fig. 3. Primitive method of combating the tentcaterpillars with a strong jet of water. (Photo R. Inst. f. t. Tropics).

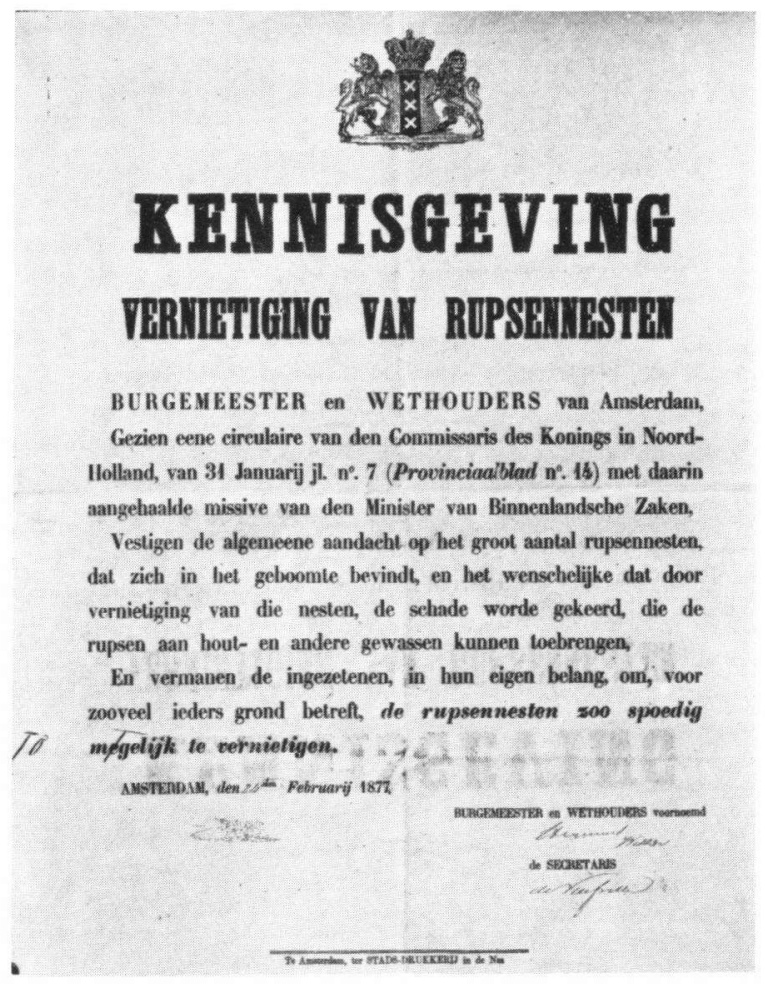

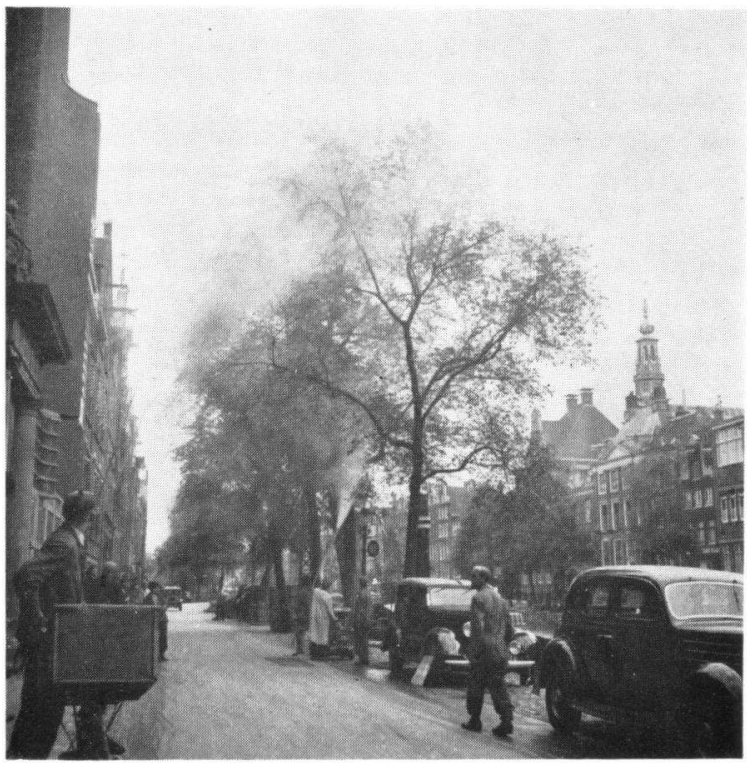

Fig. 4. Application of derris powder to Malacosoma-infested elm trees, using a motor-duster. (Photo R. Inst. f. t. Tropics).

Fig. 5. Placard of 23 February 1877 exhorting the citizens to destroy caterpillar-nests (see p. 120). 
ANONYmous, 1936, where further references can be found).

Early in May, several weeks before the official installation of the Committee an experiment was taken with derris dust against Euproctis caterpillars on oak trees in the Vondelpark, using a motor duster of the Phytopathological Service. When it became evident that it had led to success the authorities and the press were enlightened about the new project. The news was well received by the public thus encouraging the planners to continue their preparations.

The Committee, inaugurated in the Town Hall on 20 June 1936, was composed as follows: Professor L. P. De Bussy, president; Professor L. F. De Beaufort, vice-president; J. R. Koning, A. J. van LAREN (Hortulanus of the Hortus Botanicus), a representative of the Phytopathological Service, and one of the Municipal Public Health Service, members; Ir. W. Spoon (Chief of Laboratories at the Tropical Institute), acting as secretary.

In the meantime tentcaterpillars had been found on the increase in the town even more than Euproctis. Severe defoliation of the trees was evident particularly along the north-west side of the Heerengracht (between the first bridge and the Singel). A survey carried out by the personnel of the Parks and Plantation Service brought to light that some $2275 \mathrm{elm}$ trees were more or less affected in the town-centre, and mostly by tentcaterpillars only. However no dusting campaign was considered to be justifiable any more as the pupal stage of the insects had al- ready set in. Therefore the Committee confined its main activities to a mapping out of the measures to be taken in the next season.

In the scheme adopted-which since has been applied also in subsequent years-it is arranged that the personnel of the Park and Plantation Service, in charge of the maintenance of the trees-including the removal of dead branches, the regular pruning and so on-shall be on the look out for the presence of egg-rings and larval nests in the tops of the crowns. In the winter season, preferably in the months of January and February, a special gang is assigned to collect all the egg-rings from random trees in different parts of the town and to list the findings. These reports are used for a prognosis of the size and extent of the caterpillar-population in the coming season. The collected egg-rings are used for rearing the caterpillars in the laboratory for observations and experiments. It is understood that the entomologist of the Tropical Institute has to advise the Plantation Service about the date on which control operations shall be started. In the meantime the quality of the dust delivered by the dealers is checked at the chemical laboratory of the Tropical Institute. The dusting operations are carried out by the personnel of the Plantation Service with its own apparatus. During and after the dusting observations are made about the apparent effect of the treatment. Finally at the end of the season a survey is held of the degree of defoliation the trees still may have suffered.1)

\section{THE YEAR 1937}

From the large numbers of egg-rings noticed in the winter season the prognosis was made of a harmful incidence of tentcaterpillars in the spring. It was also expected that Euproctis caterpillars would be numerous. These prospects made the planning of a large scale campaign most urgent and orders were placed for a motor duster and quantities of the derris/talcum mixture of $1 \%$ rotenon. The Malacosoma eggs hatched at the end of April. High temperatures in May and the beginning of June favoured their rapid growth

1) The work assigned in the scheme to the biological laboratory of the Royal Institute for the Tropics has been carried out by different biologists in the course of the years, viz.: in 1935 and 1936 by Dr. P. A. VAN DER LAAN, from 1936 to May 1939 by Dr. A. Diakonoff, assisted in the 1938 season by the student F. Bothma, from May to December 1939 by Dr. J. G. van Houten, from 1940 until and soon the signs of a pending serious defoliation of a large extent were visible. Because the delivery of the duster was retarded the operations could not be started before the 9th of June with a machine borrowed from Wageningen (Fig. 4). Notwithstanding the size to which the caterpillars had grown in the meantime the treatment appeared to be effective, particularly when the weather was favourable for the operations. Large numbers of stunted and paralysed caterpillars fell down on the streets. But no sufficient

1945 by F. E. Loosjes, who was assisted in 1943/1944 by the student F. Blanchi, in 1946 - when there was no entomologist on the staff of the Institute - by Dr. G. Kruseman of the Zoological Museum of the Amsterdam University, in 1947 by Dr. P. A. VAN DER LAAN, from 1948-1952 by S. A. Neuwenhuizen, from 1953-1957 by Dr. L. G. E. Kalshoven. 
progress could be made to compete with the extent of the outbreak and in places not yet treated hords of caterpillars moved downward from more or less defoliated trees and spread over the streets and house fronts. Therefore the assistance of the Cleaning Service was again called in to remove the caterpillars with their jets of water (Fig. 3), but the team which appeared on the scene with three tank-lorries could not deal with more than 50 trees a day and the results were unsatisfactory also in other respects.

About the 20th of June the first caterpillars were observed to start spinning their cocoons. Dusting was continued until the 26 th of June at which date 3300 trees had been treated and $2400 \mathrm{~kg}$ dust had been used. The measures had not prevented that large numbers of caterpillars had reached maturity, the yellow cocoons often being formed in conspicuous quantities on façades of the houses, on lantern posts, railings and so on.

On June 23rd the burgomaster summoned the public to destroy as many of these cocoons as possible. Experts inspecting the situation observed however that by far the greater number of cocoons had been made between the rests of the foliage in the tree-crowns and only a rather small part within reach of the ground. The Committee therefore advised against the spending of money and labour on destroying the cocoons. It gave some satisfaction that hardly any cocoons could be found in places where dusting had been carried out at a time the caterpillars were half grown. Similar results were obtained in the laboratory where out of a thousand caterpillars fallen from trees, which had been treated, a small number eventually pupated and only $6 \%$ produced a moth while out of 150 specimens found under untreated trees $50 \%$ reached the moth stage. A considerable percentage of caterpillars collected succumbed from an epidemic disease, viz.
$23 \%$ of the just mentioned sample of 1000 specimens. Out of 450 cocoons collected from defoliated trees afterwards, more than $30 \%$ contained only the remains of caterpillars or pupae killed by the disease. Infestation by parasites appeared to have been a minor cause of mortality, viz. in only $0.5 \%$ of the caterpillars and $3 \%$ of the pupae.

It was estimated that notwithstanding the artificial and natural checks upon the pest still some 5000 trees had suffered from defoliation. The extent of the area affected can be seen from the map drawn from the notes found (Fig. 6).

Public and press had shown great interest in the outbreak and in the attempts to control it. A few writers of letters to the press had shown themselves to be rather sceptical or critical about the use of the derris insecticide. Mr. R. A. Polak, the manager of the insectarium in the Zoo, was particularly opposed to the use of any strong insecticide as he feared the whole insect fauna in parks and gardens would be destroyed, to the annoyance of the amateur entomologists, and he argued that a biological control should be applied. The polemics about this matter lasted until May 1938.

Incidentally, the mass occurrence of the caterpillars in the trees had been particularly embarrasing because a tour in open carriages during the official royal visit to the capital included some parts along the canals at the time the activity of the insects was at its highest. After the tour the upholstery of the calèches and the uniforms of the guards had to be cleaned from the pellets which had rained down on them. No wonder that some people tried to point to some persons in authority who were deemed responsible that the outbreak had not been kept in check.

\section{THE YEAR 1938}

Until the middle of March much attention was paid to searching the elm trees for the presence of eggrings in their crowns. The greatest numbers found were in the northern part of the canal-zone, viz. up to 700 on individual trees along the Heerengracht, 1000 at the Keizersgracht and 500 at the Prinsengracht. Considerable numbers of rings were observed also on the trees in the Oude Centrum with a maximum of 500 on a tree at the Groenburgwal, 100-150 on an average on trees in sections of the Zwanenburgwal, Kloveniersburgwal, O.Z. Achterburgwal, etc. Even on the Da Costakade, situated outside the
Centrum, where nearly every tree was examined, numerous egg-rings were found varying from $10-20$ to $150-200$ on trees standing in each other's vicinity. The personnel entrusted with the work was struck by the fact that trees, which had not been completely defoliated the previous year, were strongly infested with rings, whereas on those trees which had been deprived of their foliage, now little if any rings occurred.

Hatching of the eggs had already started in rings collected on 29 April, and it appeared to be completed in samples taken the 10th of May. Dusting 


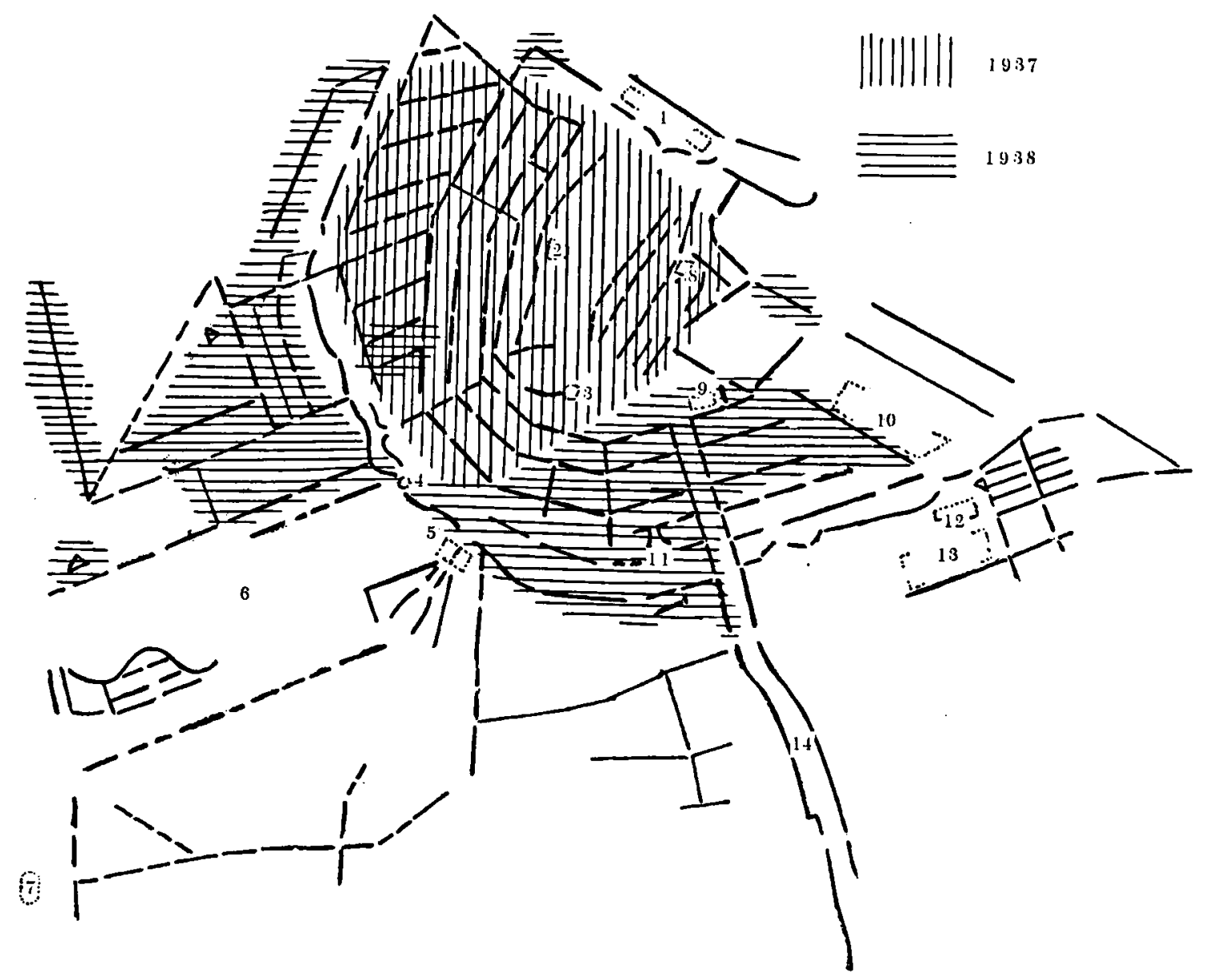

Fig. 6. Outbreak centres in 1937 and 1938 (for legend see note).

was begun by way of experiment on this date. However, about half of the young caterpillars appeared to be still alive in their nests on branches cut from trees which had been treated. This unsatisfactory result was ascribed to the low temperature, $12^{\circ} \mathrm{C}$, prevailing at the time of dusting. Much better results were obtained in the treatment of trees attacked by Euproctis caterpillars.

Dusting against Malacosoma was continued with 2 machines up to the 27 th of May. In the districts Zuid and Oost 2740 trees had been dusted with some $2500 \mathrm{~kg}$ of the powder up to that date.

Legend for figures 6-9. The thick lines represent the rows of elm trees lining the concentric canals, the cross streets and avenues, the interruptions in the lines being bridges. The dotted lines are rows of young lime trees which have replaced the old elm trees since 1945. The shaded areas indicate the extent of defoliation in the outbreak years of Malacosoma neustria.
Signs of recent defoliation, even severe in some places, were still present during an inspection on 10 June. Therefore a second dusting was started on 16 June with a stronger mixture, containing $2 \frac{1}{2} \%$ or even $4 \%$ rotenon, so that it might be effective against the growing caterpillars. Some immediate good results were noticed on several occasions where numerous caterpillars had fallen to the ground. However much difficulty was often experienced by too strong winds during the operations. Samples showed that a 65-83\% mortality of caterpillars was obtained on trees well covered with the insecticide, but that only

Numbers for the sake of orientation: (1) Central station, (2) Dam, (3) Munt, (4) Leidsche Bosjes, (5) Rijksmuseum (State Museum), (6) Vondelpark, (7) Stadion, (8) Nieuwe Markt, (9) Waterloo-plein, (10) Artis (The Zoo), (11) Frederiks-plein, (12) K. Instituut v. d. Tropen, (13) Oosterpark, (14) (River)Amstel. 
$50 \%$ were killed on trees insufficiently hit.

To prevent the numerous caterpillars fallen to the ground but not lamed, from ascending the trees a band of tanglefoot of $8 \mathrm{~cm}$ around the tree bases proved to be effective.

An experiment with burning the nests with torches soon indicated that this method was as cumbersome as clipping of the nests with pruning hooks.

The owners of private gardens where caterpillars had become troublesome were given notice by the press that they could have their trees treated by the municipal services at a small charge. In this scheme 70 garden plots were treated in the period between 9 May and 14 June, at first with dust of $1 \%$ rotenon, later on with a stronger dose.

In the last week of June still a few complaints were received about trouble caused by caterpillars on the trees lining the canals. Therefore the treatment of outbreak centres was continued until 2nd July. At that date 2630 trees had been dusted in the districts
Zuid and Oost with $2740 \mathrm{~kg}$ of the derris mixture. In district West 5580 trees had been treated at the rate of $6000 \mathrm{~kg}$ powder, bringing the total quantity used to more than $12.000 \mathrm{~kg}$.

Later it was found that the activity of the caterpillars had not even come to an end in the second week of July and that increasing loss of foliage still could be observed. However complete defoliation occurred eventually in a few places only or on individual trees. For the rest the trees attacked had bare tops and greatly thinned out foliage, this being particularly the case in the eastern part of the canal-zone on the Reguliersgracht, Weteringschans and Stadhouderskade (Fig. 6).

The fighting of the caterpillar outbreak again aroused great interest from the side of the public, which had been enlightened about the matter by a press-conference at the beginning of the campaign. Still, several letters to the editor appeared in the daily papers.

\section{THE YEAR 1939}

On January it was already evident from the small numbers of egg-rings found on branches that no massreappearance of caterpillars had to be feared. It was generally supposed that the energetic campaign of 1938 had reduced the Malacosoma population to such an extent that no new flare-up could occur. This came true and in the warm pre-summer season only some scattered cases of injury to the foliage could be noticed, for instance in places in district Oost, where no dusting had been carried out in 1938. Here a treatment of the trees with $3 \%$ rotenon dust was applied because the caterpillars had already reached a certain size.

\section{THE YEAR 1940}

Egg-rings of Malacosoma were sporadically found during the removal of Euproctis nests from elm trees in some places in the early months. According to expectation little infestation, nowhere of an alarming nature, was to be observed in May. Dusting by way of routine measure was begun on the 4th of June, but only a poor derris mixture was available as a result of war conditions, and caterpillars which had reached some size due to favourable weather appeared to be little affected by the material.

An appeal to the public to have their garden plots treated if necessary met with little response and was carried out in 7 cases only. Here the dusting could be applied more intensively and where the results were checked after three days the caterpillars were dead or unable to develop.

\section{THE YEAR 1941}

A considerable number of egg-rings was found on branches clipped for the removal of winter-nests of Euproctis from the elm trees, a measure to which much attention could be paid at the time. The Malacosoma eggs were particularly numerous on trees along the canal-zone between the Brouwersgracht and the Leidschestraat, the Rozengracht and the N.Z. Voorburgwal, foreboding renewed trouble. Eggs kept in observation began to hatch on the 14th of May. The only remaining quantity of derris-mixture available, viz. $600 \mathrm{~kg}$ of $0.8 \%$ rotenon, was used up in dusting operations from 26 May until 3 June in some 


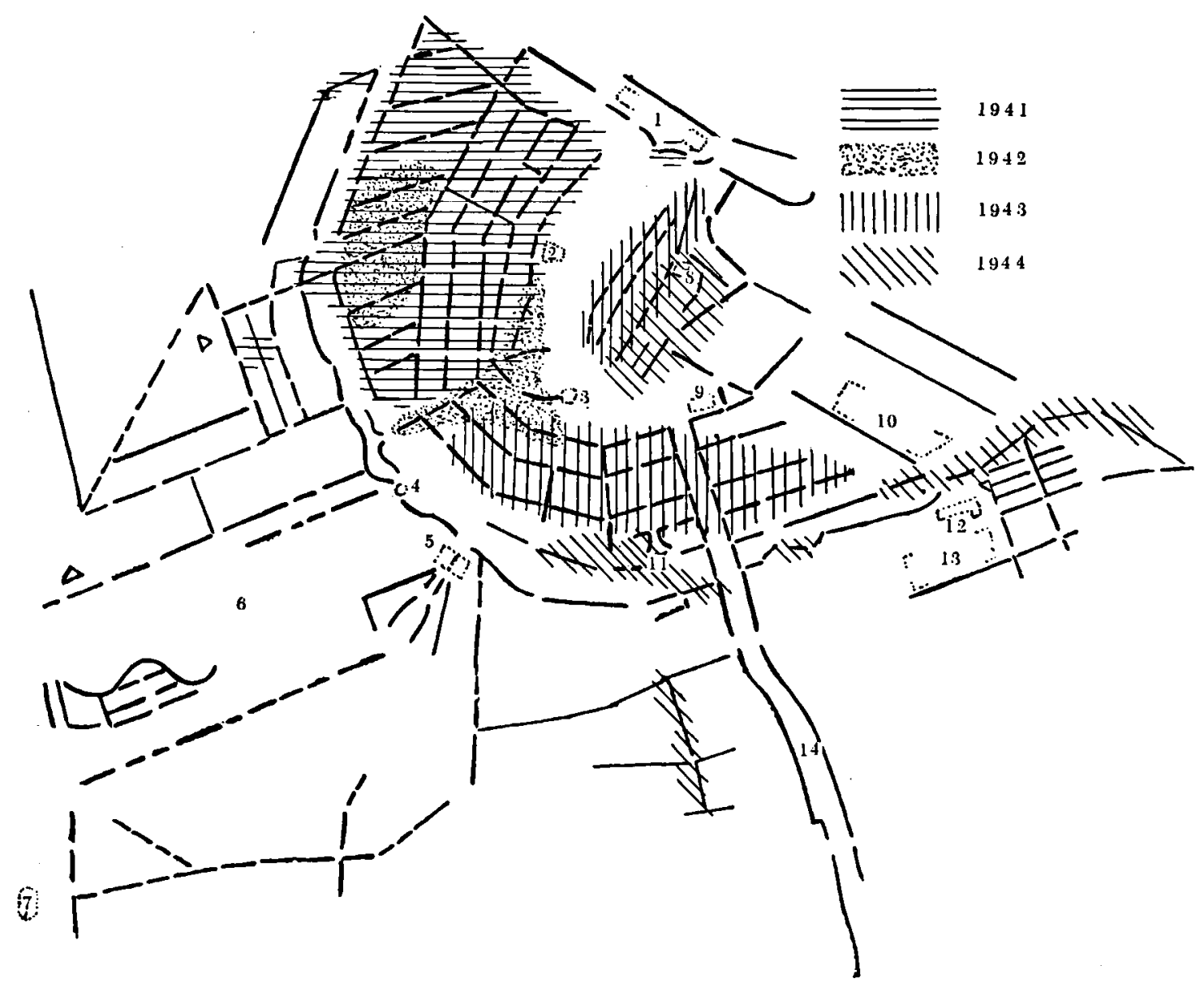

Fig. 7. Outbreak centres in 1941, 1942, 1943 and 1944 (for legend see note on p. 109).

places where an outbreak of Euproctis or Malacosoma was feared. During inspection tours held in the last week of June and the first week of July severe infestation, exclusively by Malacosoma and leading to semi or total defoliation appeared to be present in and near places where the large numbers of egg-rings had been found and no dusting had taken place. Clearly less loss of foliage was apparent in a few places where the treatment had been carried out. The caterpillars were already preparing for pupation at that time. In September numerous hatched pupae were found on the fallen leaves and new egg-rings in the crowns.

On 3 June the Polygoon Company had made a film of the dusting of the trees along the Bloemgracht and of the laboratory work done at the Royal Institute for the Tropics in connection with the control measures.

\section{THE YEAR 1942}

Countings of Malacosoma eggs in the early months showed an occurrence of up to 250 rings on trees of medium size in the north-west section of the canalzone and 50-80 in the central part. About 2500 rings were collected from 28 trees lining the Heerengracht, an average of 90 per tree. Many rings were also observed on trees in the Indische Buurt, situated eccentrically in Amsterdam Oost. In the beginning of
June defoliation became conspicuous and in places where many eggs had been found the foliage of the trees was thickly covered with caterpillars, lending a greyish tint to the crowns. Serious complaint about severe defoliation of the trees was received from the N.Z. Voorburgwal at the place where the customarily stamps-exchange market is held. No derris or other insecticide being available in war-time, control meas- 
ures could not be applied. Neither was a survey made of the final extension of the defoliations but from notes taken up to 8 June the main range of the outbreak could be mapped out afterwards (Fig. 7).
This shows the infested part of the town to border the outbreak centre of 1941 and to encompass it on the W., S. and E. side.

\section{THE YEAR 1943}

Some pruning of the trees and testing the branches for the occurrence of egg-rings was done by a small gang of climbers from January until the flowering of the trees in March. In the outbreak centres of the previous year no new eggs could be found against hundreds of old rings. Fairly careful accounts made in the S. part of the canal-zone showed an increase in the number of eggs from 6 to 45 from the Leidsche Gracht in the direction of the Amstel River, the maximum number being found in the Utrechtschestraat. Some 25-30 rings per tree were collected from 10 rather small elms in the $S$. part of the Beethovenstraat in Amsterdam Zuid. In the beginning of June nests of young caterpillars and signs of defoliation could be detected in several places by the observers. However no control could be carried out for lack of labour and materials like insecticide, petrol for the motor dusters and so on. About 20 June the caterpillars were full grown. Notes were taken about the severity of the defoliation distinguishing 5 degrees, over the whole area in the middle of July. Crowns with meagre foliage left were seen in several places but completely defoliated trees were only found in one locality on the Nieuwe Achtergracht.

The plotting on the map of the places mentioned in the reports now indicates that the central parts of infestation again had shifted and comprised the Oude Centrum and the E. part of the canal zone (Fig. 7).

\section{THE YEAR 1944}

Little was done in the way of pruning of trees in the winter season in consequence of bad war-conditions. However the development of centres of infestation by the caterpillars was followed by laboratory assistants in the end of May and in June. The state of the weather appeared to be unfavourable for the pest and the most severe damage done was a total loss of foliage of the top parts of the crowns. Again no control measures could be taken. From 20 June to I July a survey was made to assess the degrees of defoliation in the different parts. Some time after the season personnel of the Municipal Services reported that out of some 1000 trees inspected in the centre of the town $7 \%$ had lost most of their foliage and $25 \%$ a considerable part of it.

Plotting of the data reported shows that the parts of the town where the caterpillars had occurred in marked numbers coincided in part with those of 1943, but for the rest bordered them, being situated particularly more eastward (Fig. 7).

\section{THE YEAR 1945}

No search for egg-rings was made in the notorious war-winter, but a survey was carried out in June about the effects of the defoliation which had an enormous sweep. The leafless trees lent a wintry aspect to several trees. In places where the trees still showed some green only spare foliage had been left. Pupae were found on totally defoliated trees as early as 12 June, probably these were cases of forced pupation in consequence of lack of food.

The sketch made from the available notes shows the extraordinary extent of the outbreak covering the entire central part of the town as well as an extension along the Amstel River (Fig. 8).

\section{THE YEAR 1946}

Small or moderate numbers of egg-rings were counted in several places, for instance 15-30 per tree on the N.part of the canal-zone and the Oude Schans, 40-50 on the Da Costakade, $10-15$ on the Bilderdijkkade, N.Z. Voorburgwal and Geldersekade. It was feared that some severe defoliation would occur again. This 


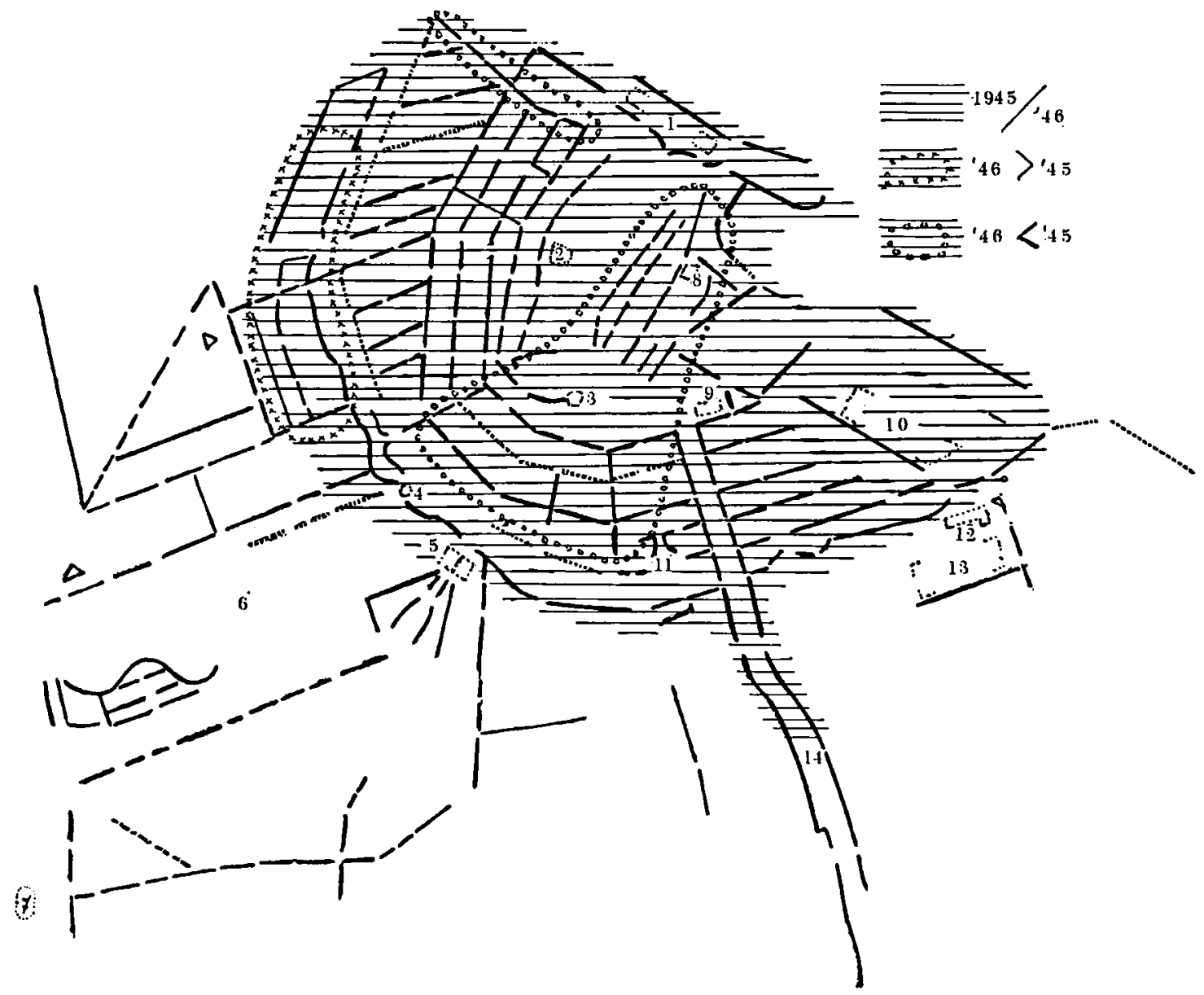

Fig. 8. Outbreak centres in 1945 and 1946 (see for legend note on p. 109).

proved true, bare tree tops becoming visible already in the end of May when the caterpillars were only half-grown. In the beginning of July caterpillars were seen leaving the trees and spreading on the façades of the houses in some localities. No sufficient quantity of insecticide on a Derris or Lonchocarpus basis was obtainable and too little was known about possible risks in using DDT in town-quarters. Once more, as an emergency matter, the caterpillars were removed as far as possible with jets of water from the machines of the Fire Brigade and the Cleaning Service in a few places. But many trees had already been deprived of their foliage at that time and the first pupae had been found. The survey of the final extent of the damage was carried out less accurately than in 1945. From the estimations noted, it can be deduced however, that defoliation more severe than in the previous year, had occurred in the Western belt of the former outbreak centre and an about equal loss of leaves in the N.W.part and also, locally, in the E. part of the canal-zone. On the other hand no damage of any importance had been done to the Oude Centrum and the S. part of the canal-zone. On the whole the area which had really suffered was distinctly smaller than in 1945 (Fig. 8).

\section{THE YEAR 1947}

Egg-rings in numbers of 20 to 30 per tree were counted in 6 places in the N.W.part of the canal-zone and the N.Z. Voorburgwal. A smaller number, up to
12 per tree, was found in 24 other places in the same part of the town and in the neighbourhood of the $\mathrm{Da}$ Costakade. Elsewhere the numbers were negligeable. 
Hatching started already in the 3rd week of April in egg-rings kept under observation. Warm weather favoured a rapid development of the caterpillars and more or less severe defoliation could be seen along several canal-sections in the middle of May. No conspicuous loss of foliage occurred in 2 of the 6 places where the largest numbers of rings had been found. Dusting was carried out from 28 May until 3 June with the use of two motor dusters and a mixture of $0.75 \%$ rotenon. A few sections of the Keizersgracht, Brouwersgracht and Leliegracht were treated a second time on the 4th of June. Caterpillars were collected a few days after the operations to check the effect. Specimens under $1 \mathrm{~cm}$ in size were nearly all dead, and mortality was very high among those of $1-2 \mathrm{~cm}$. Most specimens of larger size succumbed later in the laboratory. In spite of the low rotenon content of the dust and the fact that ground marl had been used instead of talcum, the effect appeared to be satisfactory. Total defoliation did not occur although some loss of foliage was clearly visible locally.

\section{THE YEAR 1948}

The distribution of egg-rings over the rows of trees was different again from that in 1947. More than 20-exceptionally 40 or even 65-eggs were found in random tests along the $\mathrm{N}$. canal-zone and in the $\mathrm{E}$. part of the Oude Centrum. Here more than 90 were collected from an individual tree. For the rest less than 20 rings occurred on the trees in the centre of the town. However, a few extensions of the infested

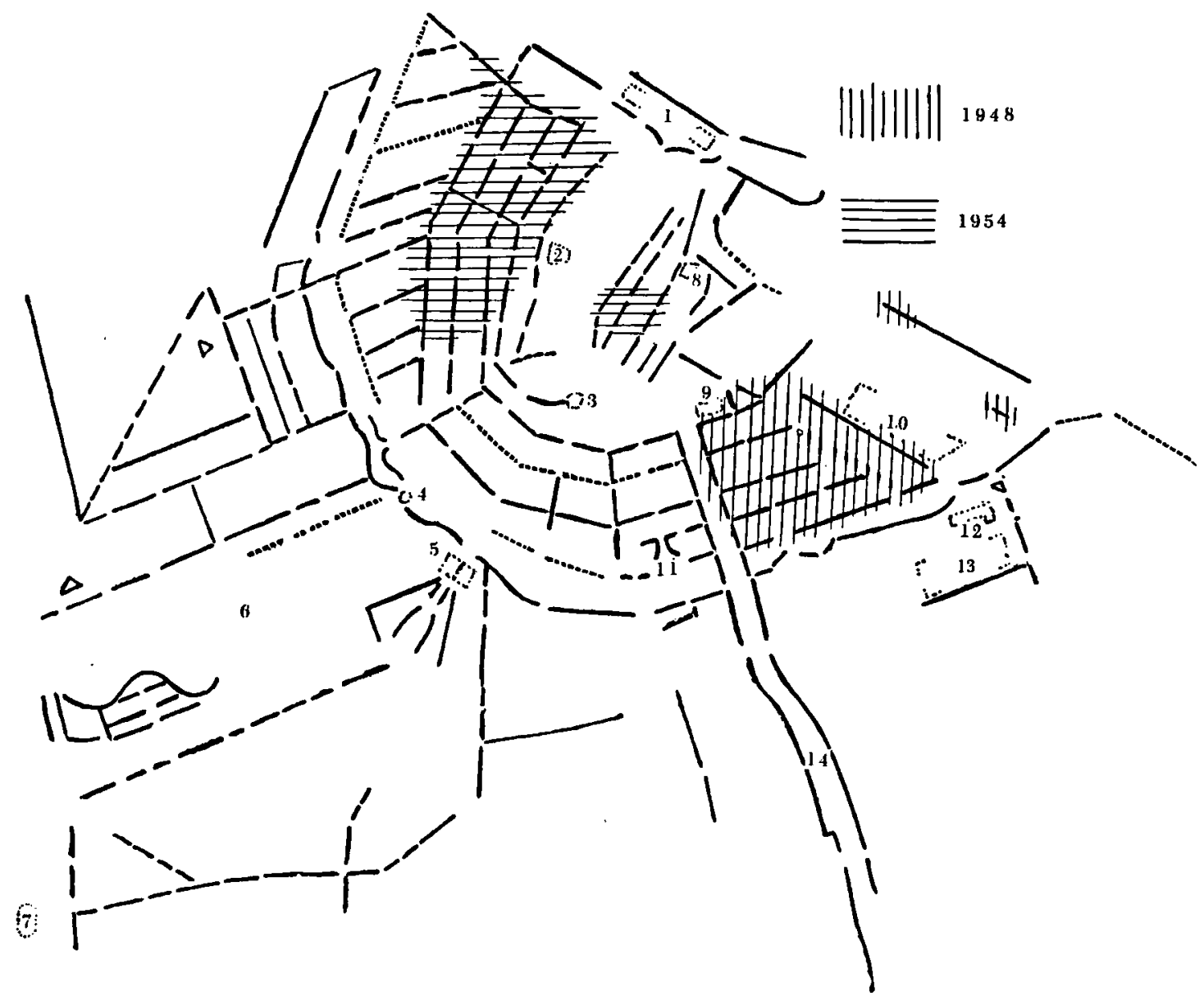

Fig. 9. Outbreak centres in 1948 and in 1954 (see for legend note on p. 109). 
area led to the East and N.West. From trees on the $\mathrm{Da}$ Costakade and Bilderdijkkade respectively 20 and 16 rings on an average were clipped.

Hatching of the caterpillars appeared to be late but in samples collected at the end of May third instar larvae were present. Dusting began on 31 May with a derris mixture in which ground marl had been used again. This resulted in a too rapid breaking up of the dust cloud which did not fully reach the tops of the highest trees. However prevailing cold and showery weather was unfavourable for the caterpillars. When the extent of the defoliation was esti- mated in the second half of July, light to heavy loss of foliage was found in several places but total loss had occurred in two spots only, including the Hoogte Kadijk, where no dusting had taken place. Contrary to expectation slight defoliation had followed in places where the largest numbers of eggs had been collected.

As may be seen from the sketch (Fig. 9) that part of the town where appreciable defoliation occurred was situated eccentrically covering about the same area as the eastward extension in 1945/1946.

\section{THE YEAR 1949}

During the pruning operations a strikingly small number of egg rings was found. On most trees they were absent; very few were collected in 8 places with a maximum of 5 rings on a tree on the Nw. Heerengracht. Dusting with a derris/talcum mixture was now carried out as a precautionary measure. In the early summer months only a few scattered trees could be detected showing traces of slight defoliation, resulting in a thinly-leaved top. Some pupae were found in the second half of July.

\section{THE YEAR 1950}

The number of egg-rings found was still smaller than in 1949 and did not amount to more than 3 on one tree. The first caterpillars were seen on the 12th of May. Routine dusting was carried out from 13-
29 June. During inspections at the end of July small traces of defoliation could be detected in the highest tops of the trees and sporadic trees had their crowns thinly leaved in a few places.

\section{THE YEAR 1951}

Most trees examined in the early months were found to be free from egg-rings but 3-5 rings were found on some trees in the Centrum while the largest number, viz. 7 rings, curiously enough, were collected from a tree in the Oosterpark, a comparatively eccentric place. On 23 April the first caterpillars hatched from eggs kept in a court of the Tropical Institute, but they did not survive the very cold month of May. Nests of young caterpillars could be detected in a few places only in the town on 8 June. The cold period lasted during the rest of the spring. Dusting was begun on 18 June and was also directed this time against an unusually large population of caterpillars of Orgyia antiqua occurring in some places. At the end of the season marked defoliation by Malacosoma was apparent in one locality only, viz. on two trees on the Oude Schans. Elsewhere the traces were small and limited to the outermost tops of the trees.

\section{THE YEAR 1952}

The collecting of egg rings produced still smaller numbers than in the two previous years, two rings on one tree being the maximum. On numerous trees examined in former outbreak centres not a single egg could be detected. However, a routine dusting of the main lines and groups of trees was completed.

\section{THE YEAR 1953}

In comparison with the three preceding years a slight increase was to be observed in the total number of egg-rings collected, as well as in the percentage of trees infested with egg-rings and in the average number of rings occurring on them, the maximum number found on one tree being 17. Eggs kept in observation 
hatched on 4 May. Dusting of the trees as a precautionary matter was begun on 6 June but only $2500 \mathrm{~kg}$ of the dust was available as part of the quantity delivered was rejected as it did not meet standard conditions. For the special observer some defoliation was perceptible in the first week of June, the amount of pellets found scattered on the streets being even a better indication of the activity of the caterpillars in the crown.

\section{THE YEAR 1954}

Although the number of egg-rings found during the testing of the trees was not large another increase was evident. The percentage of trees infested with eggs was twice as large as that in 1953 , the total number of rings was three times as large, the maximum number found on one tree amounting to 25 . Still the situation was not considered to be alarming. The first caterpillars hatched on 10 May.

When dusting operations were started with the use of two machines on 9 June it soon became apparent that defoliation was becoming more severe than had been expected, particularly in the N.W. part of the canal-zone and places adjacent to it. Therefore, in several instances dusting was repeated once or twice, on the Westermarkt even three times. The operations were continued until 30 June, a few additional treatments being carried out even as late as 9 and 21 July. A newspaper report of 12 July showed that the public's attention had been drawn to the activities of the caterpillars, which had led to severe defoliation even nearing total loss of foliage in various localities. On 20 July the caterpillars were not yet full-grown, this probably resulting from the cold and wet spring. They were not seen moving on the streets and on the façades of the houses.

The extent of the area of marked defoliation, as found in the middle of July is hereby given on the plan (Fig. 9).

A few observations were made about the presence of cocoons and new egg-rings in the middle of September in a few outbreak centres. Out of 300 cocoons collected from trees which had had the tops defoliated no more than $65 \%$ had hatched normally, the rest had rotted or had not produced a moth for some other reason. For a small part this could be attributed to the activity of parasitic Tachinid flies. Out of 335 cocoons on two trees which had been defoliated for $3 / 4$ or $4 / 5,45 \%$ of the pupae had failed to hatch. No new eggs were found on either of the trees examined.

\section{THE YEAR 1955}

The collecting of egg-rings, done with extra care with regards to the experience of the previous year, showed a marked decrease along the whole line in the numbers found, as may be seen from the table on p. 117. This reduction was attributed to the unfavourable conditions during the swarming and oviposition period of the moths in 1954. Caterpillars found on trees in the first week of June were only $6 \mathrm{~mm}$ long, below the normal size for that part of the season, probably a result of the cold spring. However, on 12 June some defoliation was noticed in an unusual quarter, the Ceintuurbaan, where the caterpillars had already reached a size of $27 \mathrm{~mm}$. Later on it was found that a small outbreak centre occurred in a private garden in the immediate neighbourhood, where an apple tree and a cherry tree were totally defoliated and pupae were already present in the beginning of July. In some other parts of the town only slight defoliation of the elm trees could be observed, viz. in the Oude Centrum, Westerdokstraat, the $W$. part of the canal-zone and some eccentric localities in Amsterdam Oost, Zuid and West.

The unequal development of the pest in widespread quarters made it difficult to decide on the right date for beginning the dusting operations. They were started as late as 24 June and weather conditions were often unfavourable. Contrary to former years the operations were carried out in the early morning hours between 5 and 9 o'clock when there was little traffic which enabled a better manoeuvring with the hand-carts. A second treatment had to be applied in some instances. Few caterpillars could be found fallen to the ground after the dusting and, taken to the laboratory for observation, part of them recovered.

From a sample of 37 egg-rings kept in observation until the end of July about 390 specimens of a hymenopterous egg-parasite Ooencyrtus tardus Ratz. hatched but the eggs had produced some 7400 caterpillars in the beginning, so that there was only a 5\% parasitism. (Diakonofr found a still lower figure, viz. $1.5 \%$ of the eggs infested by parasites in 1938.) From 
caterpillars collected from the crowns of the trees a fair number of the parasitic Tachinid fly Compsilura concinnata $\mathrm{Mg}$. was reared.

No lasting lack of foliage of any importance was to be observed at the end of the season, in the middle of July, on the elm trees in different parts of the town.

\section{THE YEAR 1956}

The small number of egg-rings found, again less than in the previous year-see the figures in the table on this page-indicated that a troublesome occurrence of Malacosoma caterpillars was not to be feared. Five rings or more, but not surpassing 11 per tree, were collected in the W. part of the canal-zone and in the O.Z. Voorburgwal in the old centre. Hatching of eggs began normally in the first week of May. The first signs of defoliation were visible to the trained eye at the end of this month. The continuing wet and cold spring tended to cause a slow and irregular development of the caterpillars, which possibly suffered considerable losses. A first round of routine dusting operations with a mixture containing $2 \%$ rotenon was completed from 14-27 June under bad weather conditions. A second round was done from 7-21 July. The traces of defoliation had in the meantime become more evident but they were of small extent and nowhere leading to a complete loss of leaves in the tops of the crowns. A ragged appearance of the foliage of the elm trees on the Prins Hendrikkade and de Ruyterkade was due to the occurrence of numbers of caterpillars of the vapourer moth, Orgyia antiqua L., which had begun their feeding late in May.

With regard to the small damage done by the tentcaterpillars it remained uncertain whether the dusting had caused any further decrease of the Malacosoma population.

\section{RECAPITULATION ABOUT THE OUTBREAKS}

In the last ca 30 years five outbreaks of Malacosoma have occurred in the elm trees of Amsterdam, viz. in $1929 / 1931,1936 / 1938,1941 / 1944,1945 / 1946$ with a retarded upswing in 1948, and 1954. In each case the outbreak started in the centre of the town and particularly in the N.W. part of the canal-zone comprising one of the oldest, narrow-built quarters of the town. In the years following the most heavy mass occurrence of the caterpillars, the original outbreak centre remained exempt from damage of any significance, whereas the main defoliation occurred in areas adjacent to it, a phenomenon specially noteworthy in the years 1931, 1938 and 1942. In 1938 this area covered all of the remaining part of the Centrum. In 1942/1944 outbreaks of comparatively limited extent shifted once and again to a less central part. In 1946 defoliation did not occur in most of the outbreak centres of previous years. In no case was loss of foliage observed in plantations in the outskirts of the town.

Some figures about the changing occurrence of eggrings obtained during the investigations in the years 1949-1956 are compiled in the following table:

Countings of egg-rings of Malacosoma on random elm trees

\begin{tabular}{|c|c|c|c|c|c|c|}
\hline \multirow{2}{*}{ Winter } & \multirow{2}{*}{$\begin{array}{l}\text { Number of elm } \\
\text { trees searched } \\
\text { for egg-rings }\end{array}$} & \multicolumn{2}{|c|}{$\begin{array}{l}\text { Trees infested } \\
\text { with egg-rings }\end{array}$} & \multirow{2}{*}{$\begin{array}{l}\text { Average number } \\
\text { of egg-rings } \\
\text { per tree infested }\end{array}$} & \multirow{2}{*}{$\begin{array}{l}\text { Maximum of } \\
\text { egg-rings on } \\
\text { a single tree }\end{array}$} & \multirow{2}{*}{$\begin{array}{l}\text { Total number } \\
\text { of egg-rings } \\
\text { collected }\end{array}$} \\
\hline & & total & $\%$ & & & \\
\hline $\begin{array}{l}1948 / 1949 \\
1949 / 1950 \\
1950 / 1951 \\
1951 / 1952 \\
1952 / 1953 \\
1953 / 1954 \\
1954 / 1955 \\
1955 / 1956 \\
1956 / 1957 \\
1957 / 1958\end{array}$ & $\begin{array}{l}266 \\
180 \\
265 \\
155 \\
132 \\
112 \\
147 \\
257 \\
218 \\
281\end{array}$ & $\begin{array}{r}43 \\
25 \\
35 \\
17 \\
44 \\
86 \\
108 \\
94 \\
112 \\
84\end{array}$ & $\begin{array}{l}16 \% \\
14 \% \\
13 \% \\
11 \% \\
33 \% \\
77 \% \\
73 \% \\
36 \% \\
51 \% \\
29 \%\end{array}$ & $\begin{array}{l}1.5 \\
1.3 \\
2.0 \\
1.0 \\
3.2 \\
4.8 \\
3.0 \\
2.4 \\
2.5 \\
1.7\end{array}$ & $\begin{array}{r}5 \\
3 \\
7 \\
2 \\
17 \\
25 \\
12 \\
11 \\
9 \\
7\end{array}$ & $\begin{array}{r}66 \\
33 \\
71 \\
18 \\
140 \\
416 \\
326 \\
225 \\
281 \\
140\end{array}$ \\
\hline
\end{tabular}




\section{EFFECTS OF THE CONTROL MEASURES}

An important question to be posed is: how far did the dusting operations with the derris mixture influence the course of the outbreaks in the periods 1937/1941 and 1947/1956? For the discussion this question may be split into three parts:

(1) Did the routine dusting prevent a renewed upswing of the number of caterpillars after little or no defoliation had taken place for one year or longer? This has to be answered in the negative as experiences in 1940 and 1954 have taught.

(2) Has it been possible to control a developing outbreak reducing it to smaller proportions or at least preventing total defoliation of large extent? This goal appears to have been reached in 1938 when notwithstanding a dense population of caterpillars defoliation remained restricted to a few places, albeit that this was attained after particularly intensive control measures had been carried out. Total loss of foliage did not come either in 1941, 1947 and 1948. On the other hand considerable loss of foliage occurred in 1944 (affecting up to $10 \%$ of the trees locally), 1945 and 1946, when no control-measures had been taken.

(3) Has it been possible to shorten the duration of an outbreak? This may possibly have been the case in $1938 / 1939$ too, as the outbreak rather abruptly came to an end after the intensive campaign during the spring and summer. However, as the natural factors reducing the populations were not thoroughly studied at the time, nothing can be said with certainty.

The failure of the control measures to come up fully to expectations may be explained to some degree by the fact that it appeared impossible with the restricted labour, machines and money available to cope with the situation and to treat all the infested trees at the most suitable moments and with a sufficient quantity of the dust. The tops of the highest trees could only be covered under the most favourable weather conditions. Therefore, a number of caterpillars survived, pupating normally and producing moths which oviposited again on the trees. Moreover centres of infestation in parks, large gardens of private houses, and hospitals etc. remained untreated, a drawback often alluded to by the personnel of the Parks and Plantation-Service.

What other factors may have contributed to keep the multiplication of the pest in check, to finish the outbreaks, or to cause the shifting of the outbreak centres? Observations carried out in 1938 by DiakoNOFF, and in 1956, suggest that parasites of the egg, larval and pupal stages have been of little importance. Infective diseases of larvae and pupae, however, may have had much influence, particularly the epidemic disease observed in 1937. The absence of caterpillars in former outbreak centres may have been caused by the results of over-population and the after-effects of the diseases. It may be possible also that ovipositing moths are not attracted by trees with a meagre foliage.

No special observations have been made about the bearing of bad weather conditions on the mortality of the very young caterpillars, the failure of pupation and the hindering of the normal activities of the moths.

\section{SUGGESTIONS FOR IMPROVEMENTS}

Finally we may put the question whether the control measures so far employed can be carried out with greater effect with the available means. This has to be answered in the affirmative and a few suggestions may be made here.

(1) In years of no outbreak no routine dusting operations over large areas should be carried out, but money and means should be saved and efforts concentrated on times and places where Malacosoma populations apparently are building up and defoliation to some extent has to be feared.

(2) In all instances where the dusting has to be carried out against caterpillars which have passed the second instar, for instance when weather conditions have prevented early measures or have thwarted a first treatment, a mixture of at least $3 \%$ rotenon content should be applied.

(3) Observations leading to a better prognosis of outbreaks should be intensified and it is most urgent that they should be extended with observations on several points in the bionomics of Malacosoma, which are still obscure, for instance the time of the day or night the caterpillars leave their nests for feeding, the influence of parasites, diseases and weather conditions, the effects of over-population, etc. etc.

(4) During the relatively short period of activity of the pest more use should be made of the assistance of students and amateur entomologists for the collecting of data and the investigation of material.

(5) Cooperation between the advising biologists 
and the personnel of the Park and Plantation Service should be further intensified. The latter will be more inclined to accept the viewpoints and suggestions of the former, as a better knowledge is gained about the inter-play of the main factors in the epidemiology of the Malacosoma outbreaks.

\section{SUMMARY}

A review is given of the recurrent outbreaks of the tentcaterpillar, Malacosoma neustria $\mathrm{L}_{\text {., }}$ affecting the elm trees in the city of Amsterdam in the period 1930-1957. An outbreak of the brown tail moth, Euproctis chrysorrhoea L., in 1935-1936 is also mentioned and some occasional loss of foliage through the caterpillars of the vapourer moth, Orgyia antiqua $\mathrm{L}$.

Large fluctuations in the size of the Malacosoma populations were found. After some years in which the damage was negligeable, the increase always started in the N.W. part of the centre of the city. In the following years the outbreaks moved to adjacent parts of the centre and finally sometimes even to more eccentric parts (see Fig. 6-9). However, the occurrence of really harmful numbers of tentcaterpillars was mostly restricted to the centre of the town.

The merits of the control measures which were carried out with derris/talcum powder spread by motordusters are discussed. The insecticide was thought to be the only sufficiently harmless for its use in the centre of a city. Some cases of defoliation and other inconveniences caused by the presence of crowds of caterpillars could apparently be reduced by the control measures. In several instances, however, the efficacy of the method remained doubtful.

The urgency is stressed of further studies of the bionomics of Malacosoma under local conditions and some suggestions are made for a better organization of the measures applied.

\section{REFERENCES}

Anonymous, 1936: Derriswortel. Kon. Ver. Kol. Inst., Meded. 38, p. 78-97 (p.88).

Anonymous, 1937: Toepassingen van Derris als insecticide. L.c., Meded. 41, p. 79-87 (p. 80).

AnONYMous, 1938: Toepassing van Derris in Nederland in 1937. L.c., Meded. 45, p. 64-69 (p. 65, 67).

Anonymous, 1939: Derris ter bestrijding van de rupsenplaag in Amsterdam (Report on 1938). L.c., Meded. 49, p. $72-77$.

AnONYmous, 1940: Same title (Report on 1939). L.c., Meded. 51, p. 57-58.

Anonymous, 1941: Same title (Report on 1940). L.c., Meded. 54, p. 60-61.

Anonxmous, 1943: Nederlandsche insecten en Derris. L.c., Meded. 60, p. 34-51 (p. 41, 51).

Anonymous, 1949: Derris ter bestrijding van de rupsenplaag in Amsterdam (Report on 1948). Kon. Ver. Ind. Inst., Meded. 83, p. 39.

Anonymous, 1950. Same title (Report on 1949). L.c., Meded. 88, p. 36.

Anonymous, 1951: Same title (Report on 1950). Kon. Inst. v. d. Tropen, Meded. 95, p. 28.

Anonymous, 1952: Same title (Report on 1951). L.c., Meded. 98, p. 41-44.

Anonymous, 1953: Same title (Report on 1952). L.c., Meded. 104, p. 28-30.

Anonymous, 1954: Same title (Report on 1953). L.c.,
Meded. 106, p. 41.

Anonymous, 1955: Same title (Report on 1954). L.c.; Meded. 113, p. 14-16.

Anonymous, 1956: Same title (Report on 1955). L.c., Meded. 116, p. 6-9.

Anonymous, 1957: Same title (Report on 1956). L.c. Meded. 125, p. 8-9.

BeAufort, L. F. DE, 1952: Rupsenbestrijding in Amsterdam. Ons Amsterdam (monthly paper) 4 (8), p. 114-117.

DinkonofF, A., 1938: Voorloopige mededeeling over de bestrijding van de ringelrups en de bastaardsatijnvlinder in de stad Amsterdam. (In Verslag van de Zomervergadering op 2.7.1938). Tijds v. Entom. 81, p. 81-84.

Polax, R. A., 1938. Mededeeling over rupsen van Euproctis en Malacosoma, die de Amsterdamsche boomen gedurende de laatste jaren hebben geteisterd, en over de wijze van bestrijding. Met discussie. (in Verslag v. d. Wintervergadering op 13.2.1938). Tijds. v. Entom. 81.

Polax, R. A., 1938. De Amsterdamsche Rupsenplaag. Entom. Berichten 10, p. 33-36.

Soest, A. van, 1946. Rupsenbestrijding in Amsterdam. Landbouwk. Tijds. 58 (703) (Schoevers-nummer), p. 625-627.

Spoon, W. en LoosJes, F. E., 1941. Tien jaren derrisgebruik in Nederland. Tijds. o. Plantenziekten 47 (3), p. 130-146; also published as: Kon. Ver. Kol. Inst., Bericht van de Afdeling Tropische Producten No. 167. 


\begin{abstract}
APPENDIX
Caterpillar outbreaks in Amsterdam in former times In 1943 Professor J. H. DE Bussy made some inquiries at the city archives concerning data which might have been preserved on the occurrence of caterpillar pests in former years.

Outbreaks appeared to have been mentioned as early as 1827 . In $1876 / 1877$ much harm was appar-

ently done to the trees, as a placard dated 23 February 1877 exhorts the citizens to destroy as many caterpillar nests as possible. Probably this refers to the winter-nests of the brown tail moth, Euproctis chrysorrhoea $\mathrm{L}$.

The placard is reproduced here (Fig. 5). The text, translated into English, reads:
\end{abstract}

\title{
NOTIFICATION
}

\begin{abstract}
About the destruction of Caterpillar Nests
The Burgomaster and Alderman of Amsterdam,

In view of a circular from the Provincial Governor for the King in North-Holland, dated the 31 st of January last, no. 7 (Provincial Gazette no. 14) and of the missive from the Secretary of State for Home Affairs, quoted therein,

Draw the inhabitants' attention to the great number of caterpillar nests in the trees, and to the desirability of the destruction of these in order to prevent damage to the trees and other vegetation by the caterpillars.

And request inhabitants of our city, in their own interest, to destroy caterpillar nests in their own premises as soon as possible.

Amsterdam, the 23rd of February, 1877

The Burgomaster and Alderman aforesaid The Secretary
\end{abstract}

At Amsterdam, the Local Printing Press in the Nes.

A further study of the ledgers in the archives would be mainly of historical interest, but it might shed some light on the cyclical occurrence of the outbreaks and their causes. 